\title{
Should Pakistan Liberalize Trade With India Against the Backdrop of the FTA with China? A Comparative Advantage Analysis for the Manufacturing Sector
}

Naheed Memon", Faiza Rehman**, and Fazal Rabbi ${ }^{* * * 1}$

\begin{abstract}
Pakistan and India have not yet normalized trade relations and gained the full benefits of bilateral trade despite significant developments to this end since 2011. Pakistan has yet to reciprocate the most-favored-nation status granted by India. This study investigates the benefits of trade liberalization between the two countries by studying the global competitiveness of Pakistan's industrial sector from a policy perspective. We construct a revealed comparative advantage index for manufacturing products (HS 2-digit level) for Pakistan, India, and China for the period 2003-12, and then identify the changing patterns of comparative advantage for Pakistan. We find that 18 industries should be protected upon liberalizing trade with India. These industries are termed 'vulnerable' as they have moved from either borderline competitiveness to becoming uncompetitive or vice versa. Additionally, the excessive concessions granted to China in its free trade agreement with Pakistan and the resistance to opening up trade with India may have resulted in inefficient trade, i.e., imports from a less competitive partner and exports to a less lucrative market. We aim to establish a direction for further research to determine the ex ante impact of trade with India on the economy via a change in the production levels of these vulnerable industries, given the impact of free trade with China and the availability of Chinese substitutes.
\end{abstract}

Keywords: Pakistan-India trade, revealed comparative advantage, manufacturing exports, trade liberalization.

JEL classification: F10, F11, F12.

${ }^{*}$ CEO, Manzil Pakistan.

${ }^{* *}$ Research Associate, Manzil Pakistan.

${ }^{* * *}$ Research Associate, Manzil Pakistan.

${ }^{1}$ We would like to thank Salim Raza, former governor of the State Bank of Pakistan, for his invaluable advice and insight. We are also grateful to Dr Abdul Waheed, the head of the Economics Department at Karachi University, whose scholarly input has served to ensure the academic rigor of the study. The views and opinions expressed in this paper are those of the authors and do not necessarily reflect those of Manzil Pakistan. 


\section{Introduction}

That international trade expansion is an important driver of economic growth is well documented, especially in the case of Asia. Countries such as Japan, China, the Republic of Korea, Malaysia, and Thailand experienced exceptional GDP growth by following a trade-led growth policy. However, the South Asian countries have learned little from this. While the Southeast Asian bloc has made tremendous progress by virtue of intraregional trade (61 percent of its manufacturing exports are traded within the region), trade between the SAARC member countries remains very low. Further, the expansion of regional trade, especially intraindustry trade, helps economies expand their global trade. The Southeast Asian countries hold 8.2 percent of the world's total exports while the share of the South Asian countries (Pakistan and India) is only 0.5 percent (Asian Development Bank \& Asian Development Bank Institute, 2013).

This remarkably low level of trade within South Asia is attributed mainly to the trade restrictions between Pakistan and India, given Pakistan's strategic geographical location and connectivity within the region. Unfortunately, despite numerous rounds of talks in the last decade, the two neighbors have failed to normalize trade relations. Steps taken by the Government of Pakistan to harmonize trade with India do not necessarily find favor among local industries, some of which fear that imports from India will crowd out local production-the severe domestic energy crisis and competition from other trading partners such as China has already affected local output. However, this perception is changing and a significant proportion of local industries now strongly recommend that the government lift trade barriers and negotiate a favorable trading agreement with India. Pakistan also faces pressure from international agencies to grant India most favored nation (MFN) status, which it has long withheld. Granting MFN status to all World Trade Organization (WTO) signatories is obligatory for Pakistan under the General Agreement on Tariffs and Trade (GATT).

Given the taxing nature of the problem and the concerns of the local business community, this study aims to identify sectors that require government support to attain global competitiveness. We do this by constructing a revealed comparative advantage (RCA) index for HS2 2-digit level code products for Pakistan, India, and China from 2003 to 2012. The

\footnotetext{
2 The Harmonized System of coding is an international nomenclature for the classification of traded goods on a common basis.
} 
change in RCA trends can help identify products that are showing a decline or an improvement in competitiveness over the years. Comparing RCA trends across countries also helps find evidence of inefficient trade, i.e., trade violating the theory of comparative advantage.

The study finds that 18 products require prompt government attention if they are to become more globally competitive in the long run. We recommend providing protection to these sectors in the presence of a more open trading regime in the short run. A comparison of RCA trends across these three countries shows that there are 12 items for which India has a comparative advantage over China, although Pakistan imports these items from the latter. Moreover, four (Pakistani) products that could have a large potential market in India are being sold in larger volume to China instead. This can be attributed to the artificial advantage given to China and the ease of access to the Chinese market as a result of the Pakistan-China free trade agreement (FTA) and the trade barriers enforced on the Indian side.

Both Pakistan and India have implemented numerous measures to restrict trade. These include trade based on positive lists, land route restrictions by Pakistan, and multiple nontariff barriers (NTBs) imposed by India. According to a recent report by the Pakistan Economic Forum (2013), reducing tariff barriers and NTBs could lead to a massive increase in bilateral trade (the potential trade is estimated at US\$ 10 billion compared to the current trade volume of around US $\$ 2.5$ billion).

Policymakers suggest that liberalizing trade between Pakistan and India will enhance trade within the region, given the strong probability of trade diversion to regional members. Normalizing trade with India would give it overland access to Afghanistan and the Central Asian states. Pakistan would benefit from the transit trade and gain access to the economies of Nepal and Thailand. One school of thought suggests that a significant improvement in growth rates and per capita income could be achieved in the long run by increasing trade with India on the basis of comparative advantage.

Section 2 summarizes Pakistan-India trade relations since 1947. Section 3 gives a brief overview of the literature addressing Pakistan-India trade problems and the competitiveness of different manufacturing sectors in Pakistan. Section 4 presents our empirical framework and dataset used. Section 5 reports the detailed results. Section 6 presents the study's main conclusions and implications and suggests areas for further research. 


\section{A History of Pakistan-India Trade Relations}

Immediately after Partition in 1947, the trade volume between the two countries was considerably high as both depended heavily on each other. However, there was a dramatic decline in trade in 1949 when Pakistan decided not to devalue its currency, rendering the trade balance unfavorable for India. Subsequently, trade was completely paralyzed as a consequence of the 1965 and 1971 wars.

The situation improved in 1975 (see Maini \& Vaid, 2012) when the two countries signed a trade agreement. Both continued trading without any mutual agreement and in 1982, the Pakistan government announced a positive list of 40 items. Bilateral trade during the 1990s was marked by fluctuations but registered an overall increase. This can be attributed to the trade liberalization regime adopted by both countries on joining the WTO in 1995; India granted Pakistan MFN status in 1996.

A major development during the next decade was the South Asia Free Trade Area (SAFTA) agreement of 2004. The SAARC countries agreed to decrease their tariffs to $0-5$ percent by 2013 . As a consequence of this agreement and the trade talks initiated by President Pervez Musharraf in 2005, bilateral trade reached a record high. In 2010, bilateral trade stood at US\$ 2.2 billion compared to US\$ 1.5 billion in 2006. Since then, the issue has received special attention: trade talks between Pakistan and India are carried out episodically in academic, business, and diplomatic circles.

The main development since 2011 has been the elimination of the positive list (see Table 1). Instead, a negative list ${ }^{3}$ was introduced and the number of products that could be traded by road was increased from 40 to 137. However, the promise that Pakistan would reciprocate with MFN status for India by December 2012 remains unfulfilled.

Table 1: Policy developments since 2004

\begin{tabular}{ll}
\hline Year & \multicolumn{1}{c}{ Policy changes } \\
\hline 2004 & Positive list comprising 757 items allowed to be traded \\
2006 & Positive list expanded to 1,075 items \\
2009 & Positive increased to 1,934 items \\
\hline
\end{tabular}

\footnotetext{
${ }^{3}$ SRO 280, issued by Pakistan's Ministry of Commerce on 20 March 2012, lists 1,209 items not importable from India. It also lists 137 items that may be traded overland (see http://www.tdap.gov.pk/.php). In January 2014, the item petroleum coke was also permitted for trade across the Wagah-Attari border (see http://www.dawn.com/news/1079280/import-ofpetroleum-coke-allowed-by-road-from-india).
} 


\begin{tabular}{ll}
\hline February 2012 & $\begin{array}{l}\text { Positive list abolished } \\
\text { March 2012 }\end{array}$ \\
& $\begin{array}{l}\text { Negative list comprising 1,209 items introduced; 137 items allowed } \\
\text { to be traded via land }\end{array}$ \\
\hline
\end{tabular}

Source: Authors' compilation.

\subsection{The MFN Story}

Both Pakistan and India joined the WTO on its formation in 1995. According to Article I of GATT, it is incumbent on all WTO signatories to trade with each other according to the MFN principle. India complied with this and granted Pakistan MFN status soon after joining the WTO, but the latter has yet to reciprocate.

MFN treatment ensures nondiscriminatory trading terms among WTO members. It guarantees that if favorable tariff rates are given to one trading partner, then all other member countries will receive the same terms. The principle does not entail giving extra advantages to any one partner; rather, it provides for uniform terms of trading for all member countries. However, not all countries fulfill this obligation. In addition to allowing the formation of preferential trade agreements (PTAs) and FTAs, some GATT clauses ${ }^{4}$ allow one country to discriminate against the other. For instance, the US has not awarded China unconditional MFN status because of its communist regime.

Pakistan decided to accord MFN status to India only as recently as 2011. In 2012, it was decided that the two countries would enjoy mutual MFN treatment from January 2013. The present government is expected to fulfill this promise soon as it faces considerable pressure to do so from the local business community and international donor agencies. One of the main reasons for not according MFN status to India concerns the NTBs imposed on the Indian side. These are complex and range from quality assurance and physical inspection by customs officials to visa issuance. NTBs account for a significant proportion of the overall trade restrictiveness index (OTRI) for India (see Table A in the Annex).

\section{Literature Review}

A number of studies on India-Pakistan trade have examined the impediments to trade, the potential trade volume, and the advantages and disadvantages of normalizing trade between the two countries. Most of

\footnotetext{
${ }^{4}$ See Articles XX and XXI for general exceptions in the text of the GATT 1968. A special exception was included for Pakistan and India (paragraph 11, Article XXIV).
} 
these also investigate the impact of trade liberalization on indicators such as consumer surplus, producer surplus, welfare, and tariff revenue. The current annual trade volume between Pakistan and India is approximately US\$ 2.5 billion, which, Khan (2013) argues, could potentially reach US\$ 50 billion in the long run under an open trade regime. Over the next five years, the estimated trade volume is expected to range between US\$6 billion and US\$ 10 billion-an estimate with which most studies concur. The Pakistan Economic Forum (2013) also estimates potential future bilateral trade at US $\$ 10$ billion.

Gopalan, Malik, and Reinert (2013) apply a partial equilibrium, imperfect substitutes framework to the items on a negative list between Pakistan and India. Assuming a constant elasticity of substitution between imports from India and imports from the rest of the world, the authors run simulations using the general algebraic modeling system to estimate the impact of trade liberalization on import volume, net output, tariff revenue, consumer surplus, and net welfare. They find that granting MFN status to India would result in a considerable degree of import substitution toward India; it would have a moderate impact on output and increase overall tariff revenue and net welfare. However, the tariff revenue gains become losses if the simulations are run assuming a free trade regime under SAFTA and the substitution toward Indian imports increases slightly. An important finding of this study is the significant negative impact on domestic output in three sectors-footwear, sporting goods, and leatherunder the SAFTA regime.

Raihan and De (2013) employ a global trade analysis project model and find that Pakistan's overall exports and imports change minimally under MFN treatment, but increase a little under SAFTA along with MFN tariffs. There is significant evidence of substitution toward the Indian market for imports. On liberalizing trade, the increase in imports from India is significantly greater than the increase in Pakistan's exports to its neighbor, but overall welfare rises for both countries. There is no correspondingly large increase in Pakistan's exports to India because Pakistan's export basketare largely less diversified and comprises low technology manufacturing products.

Several studies have investigated the problems faced by Pakistan's industrial sector, using different quantitative and qualitative methods to understand the competitiveness of manufacturing sector exports in a global market context. Yousuf (2009), in discussing manufacturing exports under the liberalization reforms of the 1990s and 2000s, reports that the structure 
and composition of Pakistan's export base has not changed in any substantial way. He highlights the importance of structural reforms needed to transform the sector in order to specialize in high technology/high value-added products.

Lall and Weiss (2004) present similar findings: industry in Pakistan has failed to adapt to the world's changing production patterns or transform from being labor/resource-intensive to technology-intensive. Their study assesses the performance of 20 main manufacturing exports of Pakistan at the SITC 5 -3 level. They conclude that significant investment in physical infrastructure and research and development as well as proper firm-level assistance is critical to address broader competitiveness issues, especially related to technological upgrading.

Mahmood (2004) reports that, among the top 25 most competitive industries (based on comparative advantage), 20 are labor-intensive. Calculating the RCA index for Pakistan's manufacturing products at the HS 4-digit level code from 1990 to 2000, he examines the comparative advantage of 978 product lines in 2000 against the average of the previous three years (1997-99). These products are categorized as competitive, noncompetitive, threatened, or emerging in order to develop an overall export profile. The author points out that trade liberalization alone will not boost manufacturing exports; instead, it poses a potential threat to the competitiveness of the major exporting sectors, given their lack of technological advancement and labor intensity. The study recommends efforts at the micro- and macro-level to sustain and achieve global competiveness.

Drawing on the comparative advantage theory, Taneja, Ray, Kaushal, and Chowdhury (2011) construct an RCA index for those product lines prohibited by India for import from Pakistan under SAFTA. They find that Pakistan does not enjoy a competitive advantage for most of the products included in the sensitive list. On liberalizing trade, therefore, the Indian economy will not face a significant influx of imports from Pakistan. The authors propose reducing the extensive list of 686 items to only 67.

Numerous studies have employed a comparative advantage technique to identify the export potential and competitiveness of a particular product from Pakistan's export basket in the global market. Variations in the RCA index point to shocks that have affected the production or export of a particular product and represent its global

${ }^{5}$ Like the HS Convention, the Standard International Trade Classification (SITC) also classifies commodities traded internationally. 
competitiveness. For example, Akhtar, Zakir, and Ghani (2008) compare the RCA of footwear produced by Pakistan, India, and China and conclude that, although India and China have a higher static comparative advantage over Pakistan, the competitiveness of the latter's footwear industry is rising while that of the other two is declining over time. Shahab and Mahmood (2012) report similar results for the leather industry. Other studies, such as Hanif and Jafri (2006), Tahir et al. (2012), and Riaz and Jansen (2012) have analyzed textiles, tomatoes, and other agricultural products, respectively, using the RCA index. They examine the international trade competitiveness of Pakistan's products relative to that of existing or potential trading partners.

The literature reveals three key points. First, there is substantial potential for trade between Pakistan and India. Second, the trade balance will likely favor India as there will be substantial substitution toward the Indian market for imports, whereas the increase in exports will be comparatively small. Third, in order to increase its manufacturing exports, Pakistan must significantly improve its industrial sector through structural reforms and technological upgrading to diversify and enlarge the country's export basket.

Our study also employs the comparative advantage technique, but unlike the studies above, the RCA index is constructed for all manufacturing products at an aggregate level, i.e., the HS 2-digit code level, in order to identify which industries need in-depth analysis. Moreover, we show the pattern of RCA for three countries for a recent period, i.e., 2003 to 2012. Using the RCA indices, the study also finds evidence of inefficient trade.

\section{Empirical Framework}

Our analysis is restricted to the manufacturing sector as it has already been established that liberalizing trade in agriculture will benefit Indian farmers due to the provision of heavy subsidies to the Indian agriculture sector (Pakistan Economic Forum, 2013). The study constructs an RCA index for all manufacturing products at the HS 2-digit level code for Pakistan, India, and China for the period 2003 to 2012. Reinert, Rajan, Glass, and Davis (2009) define RCA as "an empirical measure of the extent to which a given country specializes in the export of a particular product or range of products, compared with the world." 


\subsection{Methodology} advantage:

RCA is calculated using Balassa's (1965) measure of comparative

$$
R C A=\left(\sum X_{i j} / \sum X_{T j}\right) /\left(\sum X_{i w} / \sum X_{T W}\right)
$$

where $i$ and $j$ are, respectively, the good and the country in question; $X_{i j}$ is the export of good $i$ by country $j ; \sum X_{T j}$ is the total exports of country $j$; $X_{i w}$ is world exports of good $i$; and $\sum X_{T W}$ is total world exports.

RCA values can range from 0 to positive infinity. A country has comparative advantage in the production of a particular product if the calculated RCA value is greater than 1 . An RCA value of less than 1 indicates comparative disadvantage. Hence, by analyzing the RCA indices for three countries, we can identify the products/industries in which Pakistan has a comparative advantage over India and China. A change in the RCA for any particular sector over time for Pakistan, India, and China is understood as a change in global competitiveness over time. Similarly, an RCA trend indicates the ability of a particular sector of the economy to capture the global market.

Sanidas \& Shin (2010) argue that using RCA to calculate comparative advantage has several benefits. It helps assess the relative performance of a country's exports over a period of time. It is reasonably accurate when transportation costs are not too high and, hence, appropriate for our analysis of Pakistan-India trade. It can also be used in econometric analysis. Above all, RCA is simple to calculate and the required data (on exports) is easily available. In contrast, for instance, the Lafay $^{6}$ index, which estimates the comparative advantage between two countries, requires both import and export data and, therefore, is more suited to analyzing intra-industry trade. This would make the Lafay index an inaccurate measure for Pakistan-India trade because intra-industry trade between the two countries is small.

\subsubsection{Trend Analysis}

We carry out a trend analysis of Pakistan's RCA index to identify which industries had a comparative advantage but have lost it over time, i.e., the RCA has dropped to less than 1 (from advantage to disadvantage).

\footnotetext{
${ }^{6}$ An index of specialization or RCA that takes into account both the exports and imports of a particular sector or product.
} 
The analysis also separates out those industries that have shown a gradual improvement over the years, but are not yet able to achieve or maintain global competitiveness. Most of these industries will have an RCA between 0 and 1 , such that $0<R C A_{i}<1$, but some will still face difficulties in maintaining the comparative advantage they have attained and fluctuate around 1 (from disadvantage to advantage). These two types of industries are labeled "vulnerable" and we recommend they be protected and helped to gain and sustain global competitiveness in the future.

\subsubsection{Inefficient Trade}

In order to find evidence of inefficient trade, we have included China as a reference country for the reasons below:

- Pakistan has recently completed an FTA round with China.

- As a result of the FTA, Pakistan's overall imports from China increased by 80 percent. Surprisingly, the import of products in the "no concession category" (i.e., the category in which Pakistan did not provide tariff concessions) increased by 174 percent (Pakistan Business Council, 2013).

- Both India and China share a border with Pakistan, but transportation costs are higher for China than for India.

Next, we compare the trends of the RCA indices for China and India for products in which Pakistan is the least competitive. This threecountry comparison enables us to separate out those products for which India's RCA is higher than that of China, which in turn is higher than that of Pakistan, i.e., $R C A^{I}>R C A^{c}>R C A^{P}$. The study then reviews the share of India and China in the overall imports of Pakistan for products that fulfill this criterion. A larger Chinese share of these products indicates that the blockage of trade with India has resulted in imports from a less competitive partner, thus resulting in inefficient trade.

Similarly, we identify another group of products for which Pakistan has the highest comparative advantage of the three countries, i.e., $R C A^{P}>$ $R C A^{c}>R C A^{I}$. For these products, India is at a greater disadvantage than China. The study compares the shares of India and China in Pakistan's export basket for these products. A lower Indian share indicates export inefficiency: Pakistan is exporting more to China than to India despite the fact that the potential for growth is higher in the latter. 


\subsection{Data Sources}

Our primary source of data is the United Nations Commodity Trade Statistics database, which provides access to international merchandise trade statistics. The dataset is a comprehensive source of import and export data, ranging from 2- to 8-digit HS code levels. Other sources include datasets available from the International Trade Center, the WTO, and the Pakistan Bureau of Statistics.

\section{Results}

The competitiveness profile of Pakistan's manufacturing product lines at the HS 2-digit level, based on the trend of the RCA index over a decade, gives us three main categories of products: (i) products that show a rising RCA trend, (ii) products that show a declining trend, and (iii) products that have either no definite trend or display smooth behavior over the years. The study finds that 19 product lines show an increasing trend and 17 product lines show a declining trend from 2003 to 2012. The majority of product lines fall in the third category (see Table $\mathrm{A}$ in the Annex). Table 2 lists the rising and falling sectors. The number in parentheses gives the exact count of product lines at the HS 2-digit level that can be classified in one sector. For the codes and names of each product line, see Table B in the Annex.

A falling or rising trend is not, however, a sufficient criterion for industries to require protection. The main aim of this trend analysis is to identify which industries require immediate help either to sustain or attain global competiveness. We find that two types of product lines/industries qualify for favorable treatment: (i) industries trying to reach the comparative advantage benchmark of an RCA value of 1 (moved from a comparative disadvantage to an advantage), and (ii) industries that have fallen below this benchmark over time (moved from a comparative advantage to a disadvantage). 
Table 2: Industries with rising and falling RCA trends, 2003-12

\begin{tabular}{ll}
\hline Rising industries & \multicolumn{1}{c}{ Falling industries } \\
\hline Primary milling products (5) & Cocoa (1) \\
Salt, sulfur, etc. (1) & Tobacco (1) \\
Inorganic chemicals (1) & Mineral fuels (1) \\
Pharmaceuticals (1) & Organic chemicals (1) \\
Tanning (1) & Fertilizers (1) \\
Soap, candles, etc. (1) & Articles of leather (1) \\
Raw hides, fur-skin, wool, animal hair (2) & Manmade filament (1) \\
Photography goods (1) & Yarns (1) \\
Paper (1) & Textiles (carpets, worn clothing, knitted \\
Precious metals and pearls (1) & fabrics and articles, etc.) (4) \\
Cotton and textiles (2) & Footwear (1) \\
Copper, iron, or steel articles (2) & Toys (1) \\
& Aircrafts (1) \\
& Explosives (1) \\
& Misc manufacturing goods (1) \\
\hline Total products $=19$ & Total products = 17 \\
\hline
\end{tabular}

Out of 83 products at the 2-digit level, 13 fall under the first category and five under the second (see Table 3). The table's first column lists those product lines that are trending upward in global competitiveness, but have either failed to cross 1 on the RCA index or have crossed 1 and are finding it difficult to sustain. The second column lists those product lines with a declining RCA that has fallen below 1 . The Annex gives the RCA indices for all these products.

Table 3: Vulnerable manufacturing industries over 2003-12

\begin{tabular}{|c|c|c|c|c|}
\hline \multirow[b]{2}{*}{ No. } & \multicolumn{2}{|r|}{ From disadvantage to advantage } & \multicolumn{2}{|r|}{ From advantage to disadvantage } \\
\hline & Code & Product line & Code & Product line \\
\hline 1 & 19 & $\begin{array}{l}\text { Cereal, flour, starch, milk } \\
\text { preparations and products }\end{array}$ & 54 & Manmade filaments \\
\hline 2 & 20 & $\begin{array}{l}\text { Vegetable, fruit, nut, etc. food } \\
\text { preparations }\end{array}$ & 56 & $\begin{array}{l}\text { Wadding, felt, nonwovens, } \\
\text { yarns, twine, cordage, etc. }\end{array}$ \\
\hline 3 & 24 & $\begin{array}{l}\text { Tobacco and manufactured } \\
\text { tobacco substitutes }\end{array}$ & 60 & Knitted or crocheted fabrics \\
\hline 4 & 28 & $\begin{array}{l}\text { Inorganic chemicals, precious } \\
\text { metal compounds, isotopes }\end{array}$ & 64 & $\begin{array}{l}\text { Footwear, gaiters and the like, } \\
\text { parts thereof }\end{array}$ \\
\hline 5 & 30 & Pharmaceutical products & 96 & Misc manufactured articles \\
\hline 6 & 32 & $\begin{array}{l}\text { Tanning, dyeing extracts, tannins, } \\
\text { derivatives, pigments, etc. }\end{array}$ & & \\
\hline 7 & 37 & $\begin{array}{l}\text { Photographic or cinematographic } \\
\text { goods }\end{array}$ & & \\
\hline 8 & 39 & Plastics and articles thereof & & \\
\hline 9 & 48 & $\begin{array}{l}\text { Paper and paperboard, articles of } \\
\text { pulp, paper, and board }\end{array}$ & & \\
\hline
\end{tabular}




\begin{tabular}{lclll}
\hline & \multicolumn{2}{c}{ From disadvantage to advantage } & \multicolumn{2}{c}{ From advantage to disadvantage } \\
\cline { 2 - 4 } No. & Code & \multicolumn{1}{c}{ Product line } & Code & Product line \\
\hline 10 & 71 & $\begin{array}{l}\text { Pearls, precious stones, metals, } \\
\text { coins, etc. }\end{array}$ \\
11 & 73 & Articles of iron or steel & \\
12 & 74 & Copper and articles thereof \\
13 & 82 & $\begin{array}{l}\text { Tools, implements, cutlery, etc. of } \\
\text { base metal }\end{array}$ \\
\end{tabular}

\subsection{Disadvantage to Advantage}

Products in the disadvantage-to-advantage category have shown an improvement over the years, but have not yet achieved global competitiveness. The RCA index for these sectors has trended upward since 2003. The list includes products such as precious stones and fruits, which are among Pakistan's major exports to China and India, respectively. Product lines such as pharmaceuticals, plastics, paper, tools and cutlery, and tobacco are also sectors that could potentially help strengthen Pakistan's deteriorating balance of payments.

The Pakistan Business Council (2013) recommends protection for the cutlery, plastics, paper, and footwear industries, along with certain other manufacturing sectors, and lists a number of product lines that require immediate attention at the disaggregated level. However, unlike this study, which uses rapid increases in the Chinese share of these imports as a yardstick to identify vulnerable industries, we have based our findings on the principle of comparative advantage.

\subsection{Advantage to Disadvantage}

The product lines in this category are the most vulnerable as they previously had a comparative advantage in the global market, which they have lost over time. For example, the RCA value for manmade filaments dropped from 12.6 in 2003 to 0.59 in 2012. A similar deterioration has occurred in the competitiveness of other products in this group. While there are many reasons for the decline in RCA, a micro-level study of each industry is needed to account for the fall in output and exports.

The declining patterns identified in this study are consistent with the literature. For instance, we find that Pakistan's footwear industry enjoyed a comparative advantage over India till 2009 and then declined; Akhtar et al. (2008) report similar results. For knitted or crocheted fabrics, Zia (2007) illustrates how Pakistan lost its comparative advantage in the global market, but remains more competitive than India. These results are 
in line with our findings. However, in order to understand RCA trends, it is important to carry out a more sophisticated analysis to identify factors such as trade policy, natural disaster, and resource constraints, which may affect the export share of a particular product in the global trade market.

\subsection{Inefficient Trade: Comparing RCA Trends}

On segmenting the product lines according to a comparison of linear RCA trends for the three countries (based on the two inequalities defined in

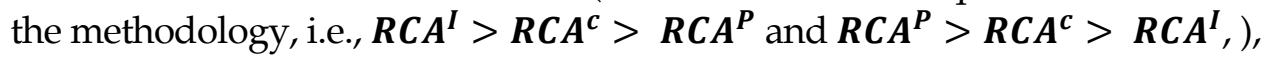
we find evidence of inefficient trade both for imports and exports.

There are 12 products for which India has a greater comparative advantage than China. According to the theory of comparative advantage, therefore, Pakistan would benefit most from importing these products from India rather than China (see Table 4). The trade data show that Pakistan imports a large proportion of these products from China (see Table C1 in the Annex). Moreover, the share of Chinese exports for these products, as for many others, has increased significantly over the last few years. In 2012, these 12 products accounted for a fourth of the total imports from China-a large enough share to signify the need to address this inefficiency.

Table 4: Industries with evidence of inefficient trade in imports

\begin{tabular}{|c|c|c|}
\hline \multirow[b]{2}{*}{ No. } & \multicolumn{2}{|r|}{ RCA India > RCA China > RCA Pakistan } \\
\hline & Code & Industry \\
\hline 1 & 21 & Misc edible preparations \\
\hline 2 & 29 & Organic chemicals \\
\hline 3 & 32 & Tanning, dyeing extracts, tannins, derivatives, pigments, etc. \\
\hline 4 & 33 & Essential oils, perfumes, cosmetics, toiletries \\
\hline 5 & 34 & Soap, lubricants, waxes, candles, modeling paste \\
\hline 6 & 38 & Misc chemical products \\
\hline 7 & 50 & Silk \\
\hline 8 & 53 & Vegetable textile fibers n.e.s., paper yarn, woven fabrics \\
\hline 9 & 54 & Manmade filaments \\
\hline 10 & 68 & Stone, plaster, cement, asbestos, mica etc. articles \\
\hline 11 & 72 & Iron and steel \\
\hline 12 & 87 & Vehicles other than railway, tramway \\
\hline
\end{tabular}

Note: The table lists Pakistan's manufacturing sector products based on their RCA pattern over 2003 to 2012, for which India is more competitive than China although Pakistan imports a significant proportion of most of these products from the latter. 
Similarly, there are four products that Pakistan could export both to India and China (Table 5). Given that India has a greater comparative disadvantage in these products than China, Pakistan should export these products to India. However, a comparison of the Chinese and Indian shares of Pakistani exports shows that exports to China (in these four products) are greater than exports to India (see Table C2 in the Annex). Exporting these products to India rather than to China would, therefore, be more lucrative for Pakistan as the market's potential to grow is greater.

Table 5: Industries with evidence of inefficient trade in exports

\begin{tabular}{|c|c|c|}
\hline \multirow[b]{2}{*}{ No. } & \multicolumn{2}{|r|}{ RCA Pakistan $>$ RCA China $>$ RCA India } \\
\hline & Code & Industry \\
\hline 1 & 42 & Articles of leather, animal gut, harness, travel goods \\
\hline 2 & 61 & Articles of apparel, accessories, knitted or crocheted \\
\hline 3 & 62 & Articles of apparel, accessories, not knitted or crocheted \\
\hline 4 & 63 & Other made-up textile articles, sets, worn clothing, etc. \\
\hline
\end{tabular}

Note: The table lists Pakistan's manufacturing sector products based on their RCA pattern over 2003 to 2012, for which India is at a greater disadvantage than China although Pakistan exports a significant proportion of most of these products to India.

\section{Conclusion}

The study has constructed RCA profiles for various manufactured products for Pakistan and its two neighboring trade partners. An analysis of these profiles yields a list of products that require immediate assistance to attain or sustain global competiveness. This includes Pakistani industries that have shown some improvement but are still struggling to achieve global competitiveness as well as those that have lost their competitiveness over time. The study suggests that these industries have the potential to grow, thus helping to strengthen Pakistan's deteriorating trade balance. The industries in question include footwear, cutlery, plastics, paper, pharmaceuticals, and others. We propose that these items be protected from additional competition once trade with India is liberalized.

The 18 product lines identified as "vulnerable" industries translate into 1,100 items at the HS 6-digit level. We recommend providing these sectors with protection in the presence of a more open trading regime in the short run. Of these 1,100 items, 284 items are already on the negative list while another 816 items are not. An industry/firm-level investigation would help assess the preparedness of these 284 products, given that they face possible removal from the negative list if India is awarded MFN status. 
Further research is needed to investigate why these industries have become vulnerable and the extent to which they should be protected. If such an investigation concludes that Pakistan's trade agreements with its partners have significantly reduced the competitiveness of these industries, a limited form of protectionism may be necessary. This prescription would be subject to assessing the impact of production in these industries on markets and welfare.

Having compared the RCA profiles of these three countries, we find that the unnecessary trade blockage with India has resulted in inefficient trade. Several items that are currently imported from China may be cheaper or better if purchased from India, given that the latter is more competitive in these products. The study also presents a list of items that should be exported to India in greater volume than to China because the former is the least competitive in these products. However, the policy implications of this result remain inconclusive without a comparison of prices, transportation costs, and the implied costs of NTBs. Since this study has used aggregate data, price comparisons were not possible and conclusive evidence of inefficiency remains a subject for further research.

The list of items identified could also be used to carry out a disaggregated inquiry of RCA profiles: we would expect the RCA for aggregated categories to differ from that of disaggregated levels within the same category of product. These results would provide policy implications for a variety of differential tariffs on different levels of production, i.e., intermediary or final goods, which are relevant for trade regime negotiations, especially in the context of a small developing open economy. 


\section{References}

Akhtar, N., Zakir, N., \& Ghani, E. (2008). Changing revealed comparative advantage: A case study of footwear industry of Pakistan. Pakistan Development Review, 47(4, Pt. 2), 695-709.

Asian Development Bank \& Asian Development Bank Institute. (2013). Connecting South Asia and Southeast Asia: Interim report. Tokyo: Asian Development Bank Institute.

Balassa, B. (1965). Trade liberalization and "revealed" comparative advantage. The Manchester School, 33(2), 99-123.

Gopalan, S., Malik, A., \& Reinert, K. (2013). The imperfect substitutes model in South Asia: Pakistan-India trade liberalization in the negative list. South Asia Economic Journal, 14(2), 211-230.

Hanif, M. N., \& Jafri, S. K. (2006). Financial development and textile sector competitiveness: A case study of Pakistan (Mimeo). Retrieved from http:/ / mpra.ub.unimuenchen.de/10271/1/MPRA_paper_10271.pdf

Khan, M. (2013). India-Pakistan trade relations: A new beginning. Washington, DC: New America Foundation. Retrieved from http:/ / newamerica.net/sites/newamerica.net/files/policydocs/ Khan_India-PakistanTrade_NAF2.pdf

Lall, S., \& Weiss, J. (2004). Industrial competitiveness: The challenge for Pakistan (Seminar Paper No. 2). Islamabad: Asian Development Bank.

Mahmood, A. (2004). Export competitiveness and comparative advantage of Pakistan's nonagricultural production sectors: Trends and analysis. Pakistan Development Review, 43(4), 541-561.

Maini, S.T., \& Vaid, M. (2012). Indo-Pak trade: A visit to historical relations (Briefing Paper No. 5/2012). Jaipur: Consumer Unity and Trust Society International.

Pakistan Business Council. (2013). Preliminary study on Pakistan and China trade partnership post-FTA. Karachi: Author.

Pakistan Economic Forum. (2013). Regional trade: Pakistan Economic Forum II. Karachi: Pakistan Business Council. 
Raihan, S., \& De, P. (2013). India-Pakistan economic cooperation: Implications for regional integration in South Asia (Working paper). London: Commonwealth Secretariat.

Reinert, K. A., Rajan, R. S., Glass, A. J., \& Davis, L. S. (Eds.). (2009). The Princeton encyclopedia of the world economy. Princeton, NJ: Princeton University Press.

Riaz, K., \& Jansen, H. G. (2012). Spatial patterns of revealed comparative advantage of Pakistan's agricultural exports. Pakistan Economic and Social Review, 50(2), 97-120.

Sanidas, E., \& Shin, Y. (2010, June). Comparison of revealed comparative advantage indices with application to trade tendencies of East Asian countries. Paper presented at the 9th Korea and the World Economy Conference, Incheon, Korea.

Shahab, S., \& Mahmood, M. T. (2012). Comparative advantage of leather industry in Pakistan with selected Asian economies. International Journal of Economics and Financial Issues, 3(1), 133-139.

Tahir, A., Shah, H., Sharif, M., Akhtar, W., \& Akmal, N. (2012). An overview of tomato economy of Pakistan: Comparative analysis. Pakistan Journal of Agricultural Research, 25(4), 288-294.

Taneja, N., Ray, S., Kaushal, N., \& Chowdhury, D. R. (2011). Enhancing intra-SAARC trade: Pruning India's sensitive list under SAFTA (Working Paper no. 255). New Delhi: Indian Council for Research on International Economic Relations.

Yousuf, K. M. (2009). Towards a vision 2030 and the challenges of openness to Pakistan economy: Export competitiveness of Pakistan's manufacturing sector, past trends and future prospects (VRF Series No. 443). Chiba: Institute of Developing Economies, Japan External Trade Organization.

Zia, U. (2007). International competitiveness: Where Pakistan stands? (Working Paper No. 28). Islamabad: Pakistan Institute of Development Economics. 
Annex

Table A: Overall trade restrictiveness index for India and Pakistan

\begin{tabular}{lrrrrrrc}
\hline & & \multicolumn{3}{c}{ OTRI } & \multicolumn{3}{c}{ OTRI_T } \\
\cline { 3 - 8 } Country & Year & ALL & \multicolumn{1}{c}{ AG } & MF & ALL & AG & MF \\
\hline India & 2009 & $14.90 \%$ & $69.47 \%$ & $13.12 \%$ & $9.41 \%$ & $43.27 \%$ & $8.31 \%$ \\
Pakistan & 2009 & $7.37 \%$ & $5.82 \%$ & $7.48 \%$ & $7.37 \%$ & $5.82 \%$ & $7.48 \%$ \\
\hline
\end{tabular}

Note: The OTRI_T focuses only on the tariffs of each country, unlike OTRI, which includes NTBs in the calculation.

Source: http://go.worldbank.org/FG1KHXSP30

\section{Table B: Classification of industries based on RCA trends}

\begin{tabular}{|c|c|c|c|c|c|c|}
\hline \multirow[b]{2}{*}{ No. } & \multicolumn{2}{|r|}{ Rising RCA } & \multicolumn{2}{|c|}{ Falling RCA } & \multicolumn{2}{|c|}{$\begin{array}{c}\text { Without any pattern or } \\
\text { smooth }\end{array}$} \\
\hline & Code & Name & Code & Name & Code & Name \\
\hline 1 & 13 & $\begin{array}{l}\text { Lac, gums, resins, } \\
\text { vegetable saps and } \\
\text { extracts n.e.s. }\end{array}$ & 18 & $\begin{array}{l}\text { Cocoa and cocoa } \\
\text { preparations }\end{array}$ & 11 & $\begin{array}{l}\text { Milling products, } \\
\text { malts, starches, } \\
\text { inulin, wheat } \\
\text { gluten }\end{array}$ \\
\hline 2 & 14 & $\begin{array}{l}\text { Vegetable plaiting } \\
\text { materials, vegetable } \\
\text { products n.e.s. }\end{array}$ & 24 & $\begin{array}{l}\text { Tobacco and } \\
\text { manufactured } \\
\text { tobacco substitutes }\end{array}$ & 12 & $\begin{array}{l}\text { Oil seed, oleagic } \\
\text { fruits, grains, } \\
\text { seeds, etc. }\end{array}$ \\
\hline 3 & 19 & $\begin{array}{l}\text { Cereal, flour, starch, } \\
\text { milk preparations } \\
\text { and products }\end{array}$ & 27 & $\begin{array}{l}\text { Mineral fuels, oils, } \\
\text { distillation } \\
\text { products, etc. }\end{array}$ & 15 & $\begin{array}{l}\text { Animal/vegetable } \\
\text { fats and oils, } \\
\text { cleavage products, } \\
\text { etc. }\end{array}$ \\
\hline 4 & 20 & $\begin{array}{l}\text { Vegetable, fruit, nut, } \\
\text { etc. food } \\
\text { preparations }\end{array}$ & 29 & Organic chemicals & 17 & $\begin{array}{l}\text { Sugars and sugar } \\
\text { confectionery }\end{array}$ \\
\hline 5 & 21 & $\begin{array}{l}\text { Misc edible } \\
\text { preparations }\end{array}$ & 31 & Fertilizers & 22 & $\begin{array}{l}\text { Beverages, spirits, } \\
\text { vinegars }\end{array}$ \\
\hline 6 & 25 & $\begin{array}{l}\text { Salt, sulfur, earth, } \\
\text { stone, plaster, lime, } \\
\text { cement }\end{array}$ & 42 & $\begin{array}{l}\text { Articles of leather, } \\
\text { animal gut, } \\
\text { harnesses, travel } \\
\text { goods }\end{array}$ & 26 & Ores, slag, ash \\
\hline 7 & 28 & $\begin{array}{l}\text { Inorganic chemicals, } \\
\text { precious metal } \\
\text { compounds, isotopes }\end{array}$ & 54 & $\begin{array}{l}\text { Manmade } \\
\text { filaments }\end{array}$ & 33 & $\begin{array}{l}\text { Essential oils, } \\
\text { perfumes, } \\
\text { cosmetics, } \\
\text { toiletries }\end{array}$ \\
\hline 8 & 30 & $\begin{array}{l}\text { Pharmaceutical } \\
\text { products }\end{array}$ & 56 & $\begin{array}{l}\text { Wadding, felt, } \\
\text { nonwovens, yarns, } \\
\text { twine, cordage, etc. }\end{array}$ & 35 & $\begin{array}{l}\text { Albuminoids, } \\
\text { modified starches, } \\
\text { glues, enzymes }\end{array}$ \\
\hline 9 & 32 & $\begin{array}{l}\text { Tanning, dyeing } \\
\text { extracts, tannins, } \\
\text { derivatives, } \\
\text { pigments, etc. }\end{array}$ & 57 & $\begin{array}{l}\text { Carpets, other } \\
\text { textile floor } \\
\text { coverings }\end{array}$ & 70 & $\begin{array}{l}\text { Glass and } \\
\text { glassware }\end{array}$ \\
\hline
\end{tabular}




\begin{tabular}{|c|c|c|c|c|c|c|}
\hline \multirow[b]{2}{*}{ No. } & \multicolumn{2}{|r|}{ Rising RCA } & \multicolumn{2}{|r|}{ Falling RCA } & \multicolumn{2}{|c|}{$\begin{array}{l}\text { Without any pattern or } \\
\text { smooth }\end{array}$} \\
\hline & Code & Name & Code & Name & Code & Name \\
\hline 10 & 34 & $\begin{array}{l}\text { Soaps, lubricants, } \\
\text { waxes, candles, } \\
\text { modelling pastes }\end{array}$ & 64 & $\begin{array}{l}\text { Footwear, gaiters } \\
\text { and the like, parts } \\
\text { thereof }\end{array}$ & 38 & $\begin{array}{l}\text { Misc chemical } \\
\text { products }\end{array}$ \\
\hline 11 & 41 & $\begin{array}{l}\text { Raw hides and skins } \\
\text { (other than furs) and } \\
\text { leather }\end{array}$ & 95 & $\begin{array}{l}\text { Toys, games, } \\
\text { sports requisites }\end{array}$ & 39 & $\begin{array}{l}\text { Plastics and } \\
\text { articles thereof }\end{array}$ \\
\hline 12 & 37 & $\begin{array}{l}\text { Photographic or } \\
\text { cinematographic } \\
\text { goods }\end{array}$ & 96 & $\begin{array}{l}\text { Misc manufactured } \\
\text { articles }\end{array}$ & 40 & $\begin{array}{l}\text { Rubber and } \\
\text { articles thereof }\end{array}$ \\
\hline 13 & 48 & $\begin{array}{l}\text { Paper and } \\
\text { paperboard, articles } \\
\text { of pulp, paper, and } \\
\text { board }\end{array}$ & 36 & $\begin{array}{l}\text { Explosives, } \\
\text { pyrotechnics, } \\
\text { matches, } \\
\text { pyrophorics, etc. }\end{array}$ & 43 & $\begin{array}{l}\text { Fur skins and } \\
\text { artificial furs, } \\
\text { manufactures } \\
\text { thereof }\end{array}$ \\
\hline 14 & 51 & $\begin{array}{l}\text { Wool, animal hair, } \\
\text { horsehair yarn and } \\
\text { fabric thereof }\end{array}$ & 60 & $\begin{array}{l}\text { Knitted or } \\
\text { crocheted fabrics }\end{array}$ & 45 & $\begin{array}{l}\text { Cork and articles } \\
\text { of cork }\end{array}$ \\
\hline 15 & 71 & $\begin{array}{l}\text { Pearls, precious } \\
\text { stones, metals, coins, } \\
\text { etc. }\end{array}$ & 88 & $\begin{array}{l}\text { Aircraft, } \\
\text { spacecraft, and } \\
\text { parts thereof }\end{array}$ & 46 & $\begin{array}{l}\text { Manufactures of } \\
\text { plaiting material, } \\
\text { basketwork, etc. }\end{array}$ \\
\hline 16 & 73 & $\begin{array}{l}\text { Articles of iron or } \\
\text { steel }\end{array}$ & 61 & $\begin{array}{l}\text { Articles of apparel, } \\
\text { accessories (knitted } \\
\text { or crocheted) }\end{array}$ & 47 & $\begin{array}{l}\text { Pulp of wood, } \\
\text { fibrous cellulosic } \\
\text { material, waste, } \\
\text { etc. }\end{array}$ \\
\hline 17 & 74 & $\begin{array}{l}\text { Copper and articles } \\
\text { thereof }\end{array}$ & 63 & $\begin{array}{l}\text { Other made textile } \\
\text { articles, sets, worn } \\
\text { clothing, etc. }\end{array}$ & 49 & $\begin{array}{l}\text { Printed books, } \\
\text { newspapers, } \\
\text { pictures, etc. }\end{array}$ \\
\hline 18 & 52 & Cotton & & & 50 & Silk \\
\hline \multirow[t]{9}{*}{19} & 62 & $\begin{array}{l}\text { Articles of apparel, } \\
\text { accessories (not } \\
\text { knitted or crocheted) }\end{array}$ & & & 53 & $\begin{array}{l}\text { Vegetable textile } \\
\text { fibers n.e.s., paper } \\
\text { yarn, woven } \\
\text { fabrics }\end{array}$ \\
\hline & & & & & 55 & $\begin{array}{l}\text { Manmade staple } \\
\text { fibers }\end{array}$ \\
\hline & & & & & 58 & $\begin{array}{l}\text { Special woven or } \\
\text { tufted fabrics, lace, } \\
\text { tapestry, etc. }\end{array}$ \\
\hline & & & & & 59 & $\begin{array}{l}\text { Impregnated, } \\
\text { coated, or } \\
\text { laminated textile } \\
\text { fabrics }\end{array}$ \\
\hline & & & & & 65 & $\begin{array}{l}\text { Headgear and } \\
\text { parts thereof }\end{array}$ \\
\hline & & & & & 66 & $\begin{array}{l}\text { Umbrellas, } \\
\text { walking sticks, } \\
\text { seat sticks, whips, } \\
\text { etc. }\end{array}$ \\
\hline & & & & & 68 & $\begin{array}{l}\text { Stone, plaster, } \\
\text { cement, asbestos, } \\
\text { mica, etc., articles }\end{array}$ \\
\hline & & & & & 69 & Ceramic products \\
\hline & & & & & 74 & Iron and steel \\
\hline
\end{tabular}




\begin{tabular}{|c|c|c|c|c|c|c|}
\hline \multirow[b]{2}{*}{ No. } & \multicolumn{2}{|c|}{ Rising RCA } & \multicolumn{2}{|c|}{ Falling RCA } & \multicolumn{2}{|c|}{$\begin{array}{c}\text { Without any pattern or } \\
\text { smooth }\end{array}$} \\
\hline & Code & Name & Code & Name & Code & Name \\
\hline & & & & & 75 & $\begin{array}{l}\text { Nickel and articles } \\
\text { thereof }\end{array}$ \\
\hline & & & & & 76 & $\begin{array}{l}\text { Aluminum and } \\
\text { articles thereof }\end{array}$ \\
\hline & & & & & 78 & $\begin{array}{l}\text { Lead and articles } \\
\text { thereof }\end{array}$ \\
\hline & & & & & 79 & $\begin{array}{l}\text { Zinc and articles } \\
\text { thereof }\end{array}$ \\
\hline & & & & & 80 & $\begin{array}{l}\text { Tin and articles } \\
\text { thereof }\end{array}$ \\
\hline & & & & & 81 & $\begin{array}{l}\text { Other base metals, } \\
\text { cermets, articles } \\
\text { thereof }\end{array}$ \\
\hline & & & & & 82 & $\begin{array}{l}\text { Tools, implements, } \\
\text { cutlery, etc. of base } \\
\text { metal }\end{array}$ \\
\hline & & & & & 83 & $\begin{array}{l}\text { Misc articles of } \\
\text { base metal }\end{array}$ \\
\hline & & & & & 84 & $\begin{array}{l}\text { Nuclear reactors, } \\
\text { boilers, machinery, } \\
\text { etc. }\end{array}$ \\
\hline & & & & & 85 & $\begin{array}{l}\text { Electrical and } \\
\text { electronic } \\
\text { equipment }\end{array}$ \\
\hline & & & & & 86 & $\begin{array}{l}\text { Railway, tramway } \\
\text { locomotives, } \\
\text { rolling stock, } \\
\text { equipment }\end{array}$ \\
\hline & & & & & 87 & $\begin{array}{l}\text { Vehicles other } \\
\text { than railway, } \\
\text { tramway }\end{array}$ \\
\hline & & & & & 89 & $\begin{array}{l}\text { Ships, boats, other } \\
\text { floating structures }\end{array}$ \\
\hline & & & & & 90 & $\begin{array}{l}\text { Optical, photo, } \\
\text { technical, medical, } \\
\text { etc. apparatus }\end{array}$ \\
\hline & & & & & 91 & $\begin{array}{l}\text { Clocks and } \\
\text { watches and parts } \\
\text { thereof }\end{array}$ \\
\hline & & & & & 93 & $\begin{array}{l}\text { Arms and } \\
\text { ammunition, parts } \\
\text { and accessories } \\
\text { thereof }\end{array}$ \\
\hline Total & & 19 & & 17 & & 43 \\
\hline
\end{tabular}

Note: The table lists the industries in Pakistan's manufacturing sector based on their RCA patterns over 2003 to 2012. 
Table C1: Share of China and India in the import of inefficiently imported products

\begin{tabular}{ccccc}
\hline & \multicolumn{4}{c}{ Country's percentage share of a particular product's import } \\
\cline { 2 - 5 } Commodity code & China, 2012 & India, 2012 & China, 2009 & India, 2009 \\
\hline 21 & 9.85 & 0.75 & 4.35 & 0.82 \\
29 & 18.36 & 15.15 & 18.18 & 22.30 \\
32 & 29.43 & 14.19 & 27.03 & 13.03 \\
33 & 16.77 & 5.46 & 5.17 & 2.90 \\
34 & 17.30 & 3.50 & 9.31 & 12.28 \\
38 & 21.38 & 9.66 & 20.56 & 6.82 \\
50 & 99.05 & 0.04 & 98.15 & Nil \\
53 & 5.86 & 0.37 & 3.55 & 0.01 \\
54 & 70.48 & 0.68 & 55.29 & 0.10 \\
68 & 41.38 & 13.01 & 36.22 & 12.23 \\
72 & 19.36 & 1.52 & 6.19 & 1.85 \\
87 & 11.24 & 0.00 & 7.97 & 0.00 \\
\hline
\end{tabular}

Note: The table presents the Chinese and Indian shares of Pakistani imports of the products listed in Table 4. These are products for which India has a comparative advantage over China.

Table C2: Share of China and India in the export of inefficiently exported products

\begin{tabular}{ccccc}
\hline & \multicolumn{4}{c}{$\begin{array}{c}\text { Percentage share of country in Pakistan's export of a particular } \\
\text { commodity }\end{array}$} \\
\cline { 2 - 5 } Commodity code & China, 2012 & India, 2012 & China, 2009 & India, 2009 \\
\hline 42 & 0.23 & 0.10 & 0.20 & 0.01 \\
61 & 0.25 & 0.08 & 0.03 & 0.03 \\
62 & 0.40 & 0.08 & 0.06 & 0.06 \\
63 & 0.70 & 0.26 & 0.31 & 0.10 \\
\hline
\end{tabular}

Note: The table presents the Indian and Chinese shares of Pakistani exports of the products listed in Table 5. These are products for which Pakistan has a comparative advantage over both China and India. 